University of New Orleans

ScholarWorks@UNO

3-1987

\title{
The Literary Transactions of Europe: An Unrecorded Continuation of the St. James's Magazine
}

\author{
Barbara L. Fitzpatrick \\ University of New Orleans, moyakniga@icloud.com
}

Follow this and additional works at: https://scholarworks.uno.edu/engl_facpubs

Part of the Literature in English, British Isles Commons

\section{Recommended Citation}

Fitzpatrick, Barbara Laning. "The Literary Transactions of Europe: An Unrecorded Continuation of the St. James's Magazine,” The Library, 6th ser., 9 (March 1987): 23-31.

This Article is brought to you for free and open access by the Department of English and Foreign Languages at ScholarWorks@UNO. It has been accepted for inclusion in English Faculty Publications by an authorized administrator of ScholarWorks@UNO. For more information, please contact scholarworks@uno.edu. 


\title{
The Literary Transactions of Europe:
}

\section{An Unrecorded Continuation of the}

\author{
St. James's Magazine
}

\author{
By BARBARA LANING FITZPATRICK
}

$\mathrm{E}$

XTANT RUNS of the St. James's Magazine (1762-64) end abruptly with the monthly number for June 1764 , a date which scholars have accepted without question as that of the periodical's demise. Contemporary newspaper advertisements, however, provide firm evidence that the magazine, following a month's hiatus, reappeared in late August with a new name, The Literary Transactions of Europe; or, Impartial Review. In this guise it survived briefly for three numbers until October 1764 , at which time advertisements ceased and the magazine presumably ended forever. The history of the publication of the magazine during 1764 is worth clarifying as a curious and significant addition to our increasing knowledge of midcentury British periodicals. Since as far as is known no copies of the three published numbers of the Literary Transactions have been recorded, discussion of the evidence for the periodical's extended run may help in locating the additional numbers. ${ }^{1}$

Surviving runs of the St. James's Magazine extend from September 1762 through June 1764 and consist of three volumes of six monthly numbers each and a shorter fourth volume of four numbers. ${ }^{2}$ Despite a promise on the last page of the June 1764 number that 'The Table of Contents, and Index to the present Volume, will be given with the next Number', extant sets end in June. ${ }^{3}$ The assumption that publication stopped permanently at that point has been reinforced by surviving copies of the fourth volume, which lack a title-page, table of contents, and index, all of which would normally have been provided with the first number of the succeeding volume. In short, evidence has always seemed to point to June 1764 as the terminal date. But changes to the title of the periodical, editorial comments in the May I764 number, and detailed newspaper advertisements printed during the summer reveal that the Literary Transactions evolved directly from the St. James's

\footnotetext{
${ }^{1}$ No mention of the Literary Transactions either as a continuation of the St. James's Magazine or as a separate periodical occurs in the British Union-Catalogue of Periodicals, Union List of Serials, National Union Catalog, British Library Catalogue, or New Cambridge Bibliography of English Literature.

${ }_{2}$ Vol. I, September 1762 to February I 763 ; Vol. 2, March 1763 to August I763; Vol. 3, September 1763 to February 1764 ; Vol. 4, March I 764 to June 1764.

${ }^{3}$ St. James's Magazine, 4 (June I764), 392.
} 
Magazine; consequently, the publication of its three numbers justifies extending the run of the St. James's Magazine through October I 764 .

The St. James's Magazine, like most mid-century periodicals, still lacks a detailed publication history, but scholars have at least established the basic facts of its brief existence to June $1764 .{ }^{4}$ Robert Lloyd was its first editor, controlling the format from September 1762 to February 1764. The St. James's Magazine was a literary miscellany, and in the opening number Lloyd stressed the originality of its contents, 'the voluntary contributions of correspondents', contrasting his new periodical favourably with the many established miscellanies which commonly augmented their contents with reprinted pieces excerpted or lifted whole from rival publications. ${ }^{5}$ Known contributors to the St. James's Magazine include Lloyd's literary friends, Charles Churchill, Bonnell Thornton, George Colman, William Cowper, and Charles Denis. The magazine yet serves as a storehouse of their original poetry, translations, and criticism. In February 1764 , however, Lloyd was imprisoned for debt, and in March control of the periodical passed to a new editor, William Kenrick. Perhaps attempting to put his own stamp on the St. James's Magazine, or perhaps responding to the pressure of new publishers, Kenrick instituted changes in aim and content which eventually led to the Literary Transactions of Europe.

While Lloyd had been in charge, the magazine had been published by an impressive array of successful booksellers. It is not clear how the literary property might have been divided, but at the outset five men shared in the venture: Flexney, Davies, and Coote in London; Jackson in Oxford; and Merrill in Cambridge. ${ }^{6}$ The inclusion of the two provincial booksellers suggests that Lloyd aimed for an audience embracing the university communities. ${ }^{7}$ By February 1764 , the probable time of the printing of the titlepage of the third volume, more names appeared in the imprint. While Coote's name was absent, those of Kearsly, Crowder, Ridley, and Blyth

\footnotetext{
${ }^{4}$ For the fullest account of the St. James's Magazine, see Lance Bertelsen, 'St. James's Magazine, The', in British Literary Magazines: The Augustan Age and the Age of Johnson, edited by Alvin Sullivan (Westport, Ct., 1983), pp. 296-99; Bertelsen errs, however, in claiming the May I 764 number as the last, and in relying solely on title-page imprints for the identities of publishers or booksellers. Brief but useful accounts are also to be found in Walter Graham, English Literary Periodicals (New York, 1930), pp. 178-79; and in Robert D. Mayo, The English Novel in the Magazines 1740-1815 (Evanston and London, 1962), pp. 298 and 378.

5 'To the Reader', St. James's Magazine, I (September 1762), [unsigned p. 3]. See also [Lloyd], 'Advertisement', and Lloyd, 'The Puff. A Dialogue between the Bookseller and Author', pp. iii-viii

${ }^{6}$ London Chronicle, I6-I 8 September 1762 . Jackson's and Merrill's names were not included on the title-page to the first volume of the magazine.

${ }^{7}$ An earlier literary magazine, The Student (1750-5I), one of whose editors was probably Bonnell Thornton, had aimed specifically at university students. It was published in London but included Oxford and Cambridge booksellers in its imprint and was notably original in content (Alan J. Gedalof, 'Student, The', British Literary Magazines: The Augustan Age and the Age of Johnson, pp. 3 I I-16). The Student may well have had some influence on the St. James's Magazine.
} 


\section{The Literary Transactions of Europe}

were now joined with Flexney's and Davies's. ${ }^{8}$ It was unusual for so many booksellers to be connected by name to a miscellany, and their number grew even larger when Kenrick began the fourth volume in March I 764 with still more changes in the imprint, including the announcement of a new printer. According to the advertisement in the London Chronicle, the March number was printed by C. Say and sold by Fletcher, Kearsly, Davies, Flexney, Davis, E. Dilly, Henderson, and Blyth. ${ }^{9}$ Only occasionally were printers singled out as such in advertisements, so the sudden appearance of Charles Say's name was probably significant. ${ }^{10}$ Also of import was the inclusion of James Fletcher's name at the head of the list of booksellers, for by the end of May 1764 the sole publisher mentioned in the magazine's advertisements was 'J. Fletcher and Co. in St. Paul's Church-yard'. ${ }^{11}$ The property evidently changed hands even as the new editor took over, though how much control if any Fletcher may have exerted over the ensuing changes in the periodical remains uncertain.

Originally Lloyd seems to have had a fairly free hand in shaping the St. James's Magazine to suit his literary taste. In an introduction 'To the Reader' in the first volume, he complained that by 1762 readers expected booksellers to have greater influence than editors in determining magazine contents. Underlying his statement was the assumption that, because booksellers were generally not men of letters, the quality of periodicals under their control had declined to a point where the very word 'magazine' in a title was enough to warn off readers of any discrimination. Lloyd maintained that

Certain it is the word MAGAZINE carries with it rather an unfavourable omen, and the editor has, it must be confess'd, at times apprehended that name might have as bad an influence upon his publication, as Shandy thought the name of Tristram had upon his son. For in the present age, when booksellers have erected themselves into proper and sufficient judges of all literary merit (which indeed, if we consider their prodigious literary property, they have some right to lay claim to) an author, who writes so apparently under their colours, as the unfortunate word MAGAZINE seems to intimate, cannot hope to be considered in any other light than as their journeyman bookmaker, till the observation of the judicious shall distinguish between the work and its title. ${ }^{12}$

Lloyd's claim of quality for the St. James's Magazine was more than the obligatory puffing to announce a new periodical: the contents lived up to his

\footnotetext{
${ }^{8}$ Coote may nevertheless still have been silently involved; for a discussion of Coote as secret proprietor of numerous magazines, see Graham Pollard, 'The Early Poems of George Crabbe and The Lady's Magazine', Bodleian Library Record, 5 (1954-56), I49-56 (pp. I 50-51).

${ }^{9}$ London Chronicle, 5-7 April 1764.

${ }^{10}$ Printers of eighteenth-century periodicals were usually anonymous. The original printer of the St. James's Magazine was Dryden Leach, whose role was revealed by Lloyd in 'The Puff', p. 3: 'The print? why there/I trust to honest LEACH's care.'

${ }^{11}$ London Chronicle, 3I May-2 June I 764.

12 'To the Reader', [unsigned, pp. 2-3].
} 
promises. Furthermore, although his stated concern over the word 'magazine' may have been exaggerated - the title he selected was, after all, the St. James's Magazine - he apparently did harbour reservations about appending a subtitle to the periodical. Walter Graham, in his brief discussion of the St. James's Magazine, points out that the concise title was unusual as it 'did not suggest or promise anything', whereas most magazines of the period did promise much by flaunting descriptive, often pretentious subtitles. ${ }^{13}$

When Kenrick assumed the editorial post, he did away with Lloyd's preference for a stark title; instead, he embellished the name with a subtitle, perhaps intending to clarify for readers the general aim of the periodical. Initially he augmented the title of the March and April I 764 numbers of the St. James's Magazine with the words, or, Literary Chronicle. At the same time he implemented changes in the contents. The magazine continued to carry original pieces, but Kenrick added book reviews which pushed the magazine more in the direction of a 'review-miscellany'. ${ }^{14}$ After two numbers, he again modified the title: in May he replaced or, Literary Chronicle with a new subtitle, or, The Literary Transactions of Europe. ${ }^{15}$ The new description carried greater weight than its predecessor, or so the first page of the May number implies. In March and April the primary title, The St. James's Magazine, appeared in large type prominently on the first page of each number, and the subtitle, Literary Chronicle, assumed a secondary role denoted, as any reader would expect, by smaller type and a position beneath the title. In May, however, Kenrick deliberately altered the relationship: while the new subtitle, The Literary Transactions of Europe, still occupied a position below the title, the large size and boldness of the type in which it was prominently set considerably diminished the words printed above it, so that by contrast The St. James's Magazine virtually faded into the page. Lest any reader should miss the none too subtle emphasis, Kenrick discussed the title change on the last page of the May number. Under 'Literary Correspondence', he offered an apology that neatly exonerated him from any blame in a matter bound to offend some readers:

Our friends of Oxford and Cambridge, who have so strenuously sollicited us to drop the title of Magazine, and adopt that of the Literary Transactions, will see how ready we are to oblige them. We cannot as yet, however, adopt a new title altogether, without running the risk of alienating the good-will of some other

\footnotetext{
${ }^{13}$ Graham, p. I79. Some examples of contemporary titles and subtitles include the Royal Female Magazine, or The Ladies General Repository of Pleasure and Improvement (1760); Imperial Magazine, or Complete Monthly Intelligencer (1760-62); and Court Magazine, or Royal Chronicle (1761-65). Lloyd edited the unsuccessful Royal Female Magazine in I760; its failure may have contributed to his sensitivity with regard to the word 'magazine', and his avoidance of a subtitle for the St. James's Magazine. 14 Bertelsen, p. 298. The category of 'review-miscellany' is based on Mayo's (pp. $215-16$ ) defini-
tion of the term.

15 St. James's Magazine, 4 (May 1764), 201.
} 


\section{The Literary Transactions of Europe}

friends and contributors. For our own part, indeed, we do not readily enter into the notion, that the mere title of a work of this nature is so momentous, as is frequently represented to us. ${ }^{16}$

- Whether or not reader pressure was the real impetus behind the title modifications, the new emphasis on the Literary Transactions of Europe threw into relief the reviews of foreign works and, indeed, during the summer of

- $\quad$ I764 Kenrick's advertisements for the magazine stressed the review element of the contents.

The June number, still entitled The St. James's Magazine; or, The Literary Transactions of Europe, was advertised as 'an impartial Account of all Books published in England or imported from Abroad: Interspersed with original Pieces of Criticism, Poetry, and Science'. ${ }^{17}$ Kenrick planned that the June number would end the fourth volume two months early, probably to bring the periodical's six-month volumes into alignment with the calendar year. But the editor's promise to include the table of contents and index to the fourth volume 'with the next Number' seems to have gone unfulfilled. After building up readers' expectations, Kendrick failed to bring out the July number - what would have been the first number of the fifth volume - as he would have normally in early August. Instead, in mid-August he inserted a notice in the Daily Advertiser acknowledging the hiatus, and promising that the periodical would recommence before the end of the month:

To the PUBLIC.

SEVERAL Letters having been received from the Purchasers of the St. JAMES's MAGAZINE; Or, LITERARY TRANSACTIONS of EUROPE; Regretting their Disappointment last Month, and offering to Subscribe towards the Continuance of that Work; which Letters having been shewn to some Gentlemen of Influence, they have exerted themselves so as to procure a sufficient Subscription to continue this Publication; among which Subscribers are a considerable Number of the Clergy of this Metropolis, and other Friends to Learning and Impartiality. The Proprietors, therefore, hope for the Favour of the Public to the next Number, which will be published on Saturday the 25 th instant, Price only $6 \mathrm{~d}$. and will be regularly continued afterwards on every other Saturday; from which many Advantages will arise to the Purchasers in Point of early Information and Entertainment. Although the Property and Direction is now in other Hands, the former proposed Plan of Impartiality will be pursued, together with many Improvements; such as Translations at full Length, of all French and Italian Pieces of a moderate Size, instead of the Scraps of Reviewers. Some Articles will be allotted for the rational Entertainment of our Female Readers, when Originals fail us; for that Purpose we shall translate such foreign Pieces as have never appeared in English: Among others, the moral Conversations of the celebrated Mademoiselle Scudery, various Pieces of Bellegarde della Casa, \&c. ${ }^{18}$

16 St. James's Magazine, 4 (May I764), 296.

${ }_{17}$ Daily Advertiser, 3 July I 764.

18 Daily Advertiser, I7 August 1764. 
In this notice Kenrick still referred to the magazine as the St. James's Magazine, describing it as 'the Continuance of that Work' - a phrase clearly relating the new periodical to the old. He stressed as well, however, significant changes in both publication and contents. The new version would be half the price of the old, would appear fortnightly rather than monthly, and would be published by 'T. Durham, at the Golden Ball, in the Strand, near Norfolk-Street; by whom Letters for the Editor are received'. ${ }^{19}$ More important, entire translations of French and Italian works of reasonable length would replace the excerpts that commonly passed for reviews of new books; as a result, so Kenrick implied, the revived periodical would fill a crucial gap among literary miscellanies, thus certainly pleasing the learned supporters of the endeavour. Also pleasing would be the fortnightly publication, a strong selling point if the periodical could provide current reviews ahead of rival monthly publications. Kenrick ended the notice by announcing a change of title to accompany the change in content: 'As the Title of Magazine will be entirely laid aside after the next Number, the Friends of this Work are requested to enquire for the Literary Transactions of Europe; or, Impartial Review'. The process of evolution that Kenrick had commenced in March with the first title alteration was now nearly complete.

The August number of the periodical seems to have served as a transitional number. In an advertisement in the London Chronicle for 25-28 August the editor gave preference to the old title, designating the periodical as 'THE St. JAMES's MAGAZINE; or, Literary Transactions of Europe, for August, I764'. At the same time, he seems not to have included with the August number, or with the two succeeding numbers, the long-promised table of contents and index to the fourth volume, for evidently no subscriber ever had those parts, or indeed the volume title-page, bound with the fourth volume. It is odd that with his emphasis on the smooth transition from the St. James's Magazine to the Literary Transactions of Europe, Kenrick did not simply go ahead and supply the missing parts. Of course, their absence may have arisen not from the editor's decision to omit them, but possibly from an accident connected with the change in publisher. When the property shifted from Fletcher to Durham yet another printer could have become involved with the periodical. If so, the title-page, contents, and index to Volume 4 could easily have been lost in the shuffle between printing houses. This explanation admittedly must remain speculative as long as no copies of the August or later numbers are available for examination.

\footnotetext{
19 The comment in the notice that 'the Property and Direction is now in other Hands' could mean not only a new publisher, Durham, but a new editor as well. The term 'Direction', however, probably refers strictly to the address for submission of letters and articles. It is likely that while the literary property shifted from Fletcher's to Durham's hands, Kenrick remained the chief editor.
} 
The advertisement for the August number noted that the next number would 'be published on the 8th of September, and continue every other Saturday'. This ambitious plan quickly became untenable. In the London

- Chronicle for 6-8 September, Kenrick was already announcing a delay in publication: 'THE LITERARY TRANSACTIONS of EUROPE, for September, Price Six-pence (late the St. JAMES's MAGAZINE) will be published on Saturday the $22 \mathrm{~d}$ of September, and not before'. The prob-

- lems, never revealed, which were forcing the editor to revert to monthly numbers before fortnightly numbers had ever begun, possibly accounted as well for the abbreviated run of the Literary Transactions. For a short time the periodical seemed to regain stability. As promised, an advertisement in the London Chronicle for 20-22 September announced 'THE LITERARY TRANSACTIONS of EUROPE. No. II. for September I764', and confidently explained that 'The Time of Publication is fixed for the last Saturday in every Month: So that the third Number will be published on the 27th of October' ${ }^{20}$ Kenrick's optimism was misplaced, it seems; a thorough search of the London Chronicle and Daily Advertiser for late October has yielded no advertisement for a third number, an ominous sign of renewed instability from which the Literary Transactions never recovered. The rapid failure of the periodical is borne out by the last traceable advertisement, in the London Chronicle for 6-8 November. It states baldly that 'The last Saturday in October was published, THE LITERARY TRANSACTIONS of EUROPE. Number III. Printed for T. Durham in the Strand'. The previous advertisements for the first two numbers had included detailed tables of contents (see Appendix) and explanations about publication dates, so by contrast the last notice is remarkable for its brevity. It offers no explanations or promises and indicates only that a third number probably was published. After that belated announcement, no more advertisements appeared for either the St. James's Magazine or the Literary Transactions of Europe.

As the Literary Transactions survived for only three numbers, it is perhaps not surprising that no copies have been recorded. The best way to have preserved the brief run would have been as a single bound volume, without a title-page, but in all likelihood the subscribers to the continuation thought three numbers too few to merit the expense of binding. ${ }^{21}$ Even if some copies were bound, the chances are slim that a volume labelled The Literary

- Transactions of Europe would have remained with the bound volumes of the

${ }^{20}$ From this advertisement it is clear that Kenrick meant the August number, regardless of title, to be Number I of the Literary Transactions. To avoid confusion, I have followed his lead, although strictly speaking that number was still entitled the St. James's Magazine; or, Literary Transactions of Europe.

${ }^{21}$ The Literary Transactions would not normally have been bound with the St. James's Magazine. The fourth volume of the latter was completed with the June 1764 number; it would subsequently have been bound either separately or together with the preceding volume. The September 1762 to June I 764 run of the St. James's Magazine held by the Ohio State University Library consists of two volumes in contemporary bindings, each comprising two volumes of the periodical. 
St. James's Magazine. Nevertheless, some copies of the Literary Transactions must still exist, perhaps bound up with partial volumes of other periodicals, or perhaps even unbound.

The evidence provided by title modifications, editorial comments, and newspaper advertisements plainly reveals that the St. James's Magazine did not end precipitately in June 1764 as scholars have believed. Rather, the new editor, William Kenrick, altered the aim of the periodical to accommodate more reviews, in particular reviews of foreign publications, and translations of foreign works. He succeeded in publishing three numbers under a new title in August, September, and October I764. Why the enterprise failed so quickly remains a mystery, but perhaps editorial statements in those undiscovered numbers of the Literary Transactions could help supply an answer, as the contents of those numbers would surely add to the periodical literature and criticism of the mid-century.

Durham, North Carolina

\author{
APPENDIX \\ Tables of Contents of the Literary Transactions of Europe for \\ August and September 1764.
}

London Chronicle, 25-28 August 1764

THE St. JAMES's MAGAZINE; or, Literary Transactions

of Europe, for August, 1764 .

Contents, I. A poetical epistle to Laura, on the Subjects of Love and Matrimony. 2. An Addition to Mr. Spence's Dialogue in his Polymetis, concerning the Farnese Globe. 3. Dryden's Epigram on Milton, an Imitation from an Epigram on Garnier. 4. A second Dissertation against pronouncing the Greek Language according to Accents. 5. Criticism on Mr. Churchill's Three Books of Gotham; with a particular Account of the last. 6. A Defence of the Minority in the House of Commons, on the Question relating to General Warrants, with Remarks. 7. To the Vauxhall Nightingale. 8. Learning without Genius: A Fable. 9. Avis au Peuple sur sa Santé; or, Advice to the People upon their Health. By Mr. Tissot. IO. A Dissertation on the Principles of human Eloquence. By Thomas Leland, D.D. with Remarks. II. Age when the Greek revived in Italy, translated from the Italian of Gradenigo.

London Chronicle, 20-22 September 1764

The LITERARY TRANSACTIONS of EUROPE.

No. II. for September 1764 .

Containing an impartial Account of all Books of Merit published in England, or imported from Abroad: Interspersed with Original Pieces of Criticism, Poetry, and Science, viz. I. The Political Pewterer, a Comedy, translated from the Danish of Baron Holberg. 2. Questions for Enquiry proposed by Mr. Michaelis to the Gentlemen sent to Arabia by the King of Denmark. 3. Tales of 


\section{The Literary Transactions of Europe}

Vade, by Voltaire; Jeanot and Colin, a Moral Tale, pointing out the ill Consequences arising from an Affectation of fashionable Life. 4. A Letter from a Gentleman at Oxford, containing a Proof of the Corona Australis from Geminus. 5. Farther Proofs of the same from Aratus, Cicero, and Germanicus. 6. A Defence of the Majority, and a Refutation of it. 7. The Times, by C. Churchill. 8. Containing every Remark made on Books by both the last Reviews, and not inserted in our last Number published a Week before them. 